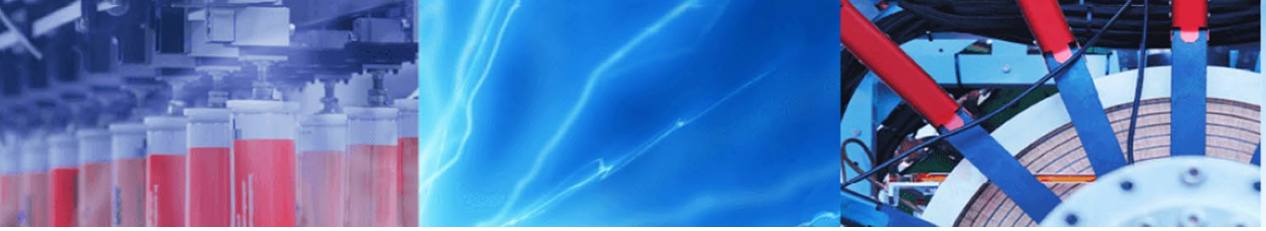

Research Article

\title{
Comparison between electrocoagulation and solvent extraction method in the process of the dechlorophyllation of alcoholic extracts from Moroccan medicinal plants Petroselinum crispum, Thymus satureioides and microalgae Spirulina platensis
}

\author{
Jihane Kouar ${ }^{1,2} \cdot$ Azzeddine Lamsaddek $^{3} \cdot$ Rajae Benchekroun $^{3} \cdot$ Abdelaziz El Amrani $^{4}$ (D) $\cdot$ Abdelmjid Cherif $^{5}$. \\ Touria Ould Bellahcen ${ }^{6} \cdot$ Nourredine Kamil $^{7}$
}

(c) Springer Nature Switzerland AG 2018

\begin{abstract}
The air-dried aerial leaves of Petroselinum crispum, Thymus satureioides and dried Spirulina platensis powder were separately extracted using a Soxhlet apparatus. The dark green solution obtained was subject to the dechlorophyllation by two techniques, the electrocoagulation and solvent extraction. The obtained absorbances, were particularly much lower for electrocoagulation process. This result showed that this technique can remove easily plant pigments in the extracts, without affecting the chemical composition on secondary metabolites.
\end{abstract}

Keywords Dechlorophyllation · Medicinal plants · Electrocoagulation · Solvent extraction · Chemical composition

\section{Introduction}

Petroselinum crispum which belongs to the family Apiaceae, is a species native to the central Mediterranean region, naturalized elsewhere in Europe and cultivated as an herb, a spice and a vegetable [1]. In Morocco, P. crispum is a medicinal plant known as the vernacular name"Baqdunis" and its extracts are known to be diuretic, smooth muscle relaxant and hepatoprotective in folk medicine [2]. The most important identified flavonoids compounds are quercetin, luteolin, kaemferol [3]. and apigenin which were found to have antiinflammatory, antioxidant and anticancer activities [4]. The chemical composition of the $P$. crispum oil was reported and a total of 34 components were identified in the literature in which myristicin and apiole were the major constituents. The presence of oxypeucedanin, a major furocoumarin in Parsley was also reported [5].

Thymus satureioides belong to Lamiaceae family. It's a North African species typical of arid habitats used in the Moroccan folk medicine in form of infuse and decoctions to treat whooping cough, bronchitis and rheumatism [6] and, generally also used, for its anti-inflammatory properties after topical or oral administration. T. satureioides is endemic species to Morocco and is a well-known aromatic

$\triangle$ Abdelaziz El Amrani, elamrani77@yahoo.fr, https://www.researchgate.net/profile/Abdelaziz_Elamrani | ${ }^{1}$ Département Chimie et Valorisation (CV), Faculté des Sciences Ain-Chock, Université Hassan II de Casablanca, BP 5366, Maârif, Casablanca, Morocco. ${ }^{2}$ Laboratoire d'Ingénierie des Procédés et d'Environnement (LIPE), École Supérieure de Technologie/Université Hassa II, Casablanca, Route d'EL Jadida, Km 7, BP 8012 Oasis, Casablanca, Morocco. ${ }^{3}$ Laboratoire Génie des Procédés et Environnement, Ecole Supérieure de Technologie, Km 7, Route d'Eljadida, P.B. 8012, Oasis, Casablanca, Morocco. ${ }^{4}$ Laboratoire Synthèse, Extraction et Etude Physico-Chimique des Molécules Organiques, Faculté des Sciences Aîn -Chock, B.P 5366, Maârif, Casablanca, Morocco. ${ }^{5}$ Laboratoire Génie des Matériaux pour Environnement et Valorisation (GEMEV), Faculté des Sciences Aïn Chock, Université Hassan II de Casablanca, Casablanca, Morocco. ' ${ }^{6}$ aboratoire Santé et Environnement, Département de biologie, Faculté des Sciences, Ain Chock, Casablanca, Morocco. ${ }^{7}$ Laboratoire de Mécanique Productique and Génie Industriel (LMPGI), Ecole Supérieure de Technologie, Université Hassan II Ain Chock, Km 7 Route El Jadida, Casablanca, Morocco.

SN Applied Sciences (2019) 1:132 | https://doi.org/10.1007/s42452-018-0137-1 
plant producing flavonoids and an essential oil, rich in borneol, with high antimicrobial effect [7].

Spirulina, is an edible blue-green microalga (cyanobacterium) characterized by multicellular cylindrical trichomes in an open left-hand helix along the entire length [8]. This cyanobacterium has received much attention in culture and as a most promising and nutritious food source due to its high content of good quality protein as well as being rich in vitamins, minerals, and other components such as essential fatty acids and antioxidant pigments like carotenoids, chlorophyll and phycocyanin [9-12].

Spirulina is widely studied, not only for its nutritional value but also for its reported medicinal properties [13]. Several studies have shown that Spirulina and its extracts could prevent or inhibit cancer in humans and animals and have immuno-promoting effects $[14,15]$, antimicrobial activity $[16,17]$, antioxidant activity [18] and antihypertensive activity $[19,20]$.

Several studies have been engaged on the chemical characterization of oil and secondary metabolites from leaf or seeds extract of the above plants. However, during the extraction, the pigments, tannins and carbohydrates are usually presents and affected the quality of the crude extract. So they must be removed so as to obtain the secondary metabolites in a purified form. This problem is more pronounced with our plants, $P$. crispum, T. satureioides and Spirulina platensis, which always contains plant pigments, notably the chlorophylls. Conventional methods for removing these substances are solvent extraction (SE) and chromatography [21-23]. However, using solvents in both methods, became more difficult to remove and as a problematic volatile chemical waste in the extracts. In chromatography, expensive and usually unrecoverable adsorbents must be used, and even then, the efficiency of pigment removal is usually far from satisfactory.

The electrocoagulation (EC), an electrochemical technique in which aluminum and iron electrodes are dissolved, generates in situ coagulant agents, which will destabilize the colloidal particles. By EC a variety of unwanted dissolved particles and suspended matter, both organic and inorganic, can be effectively removed from an aqueous solution by electrolysis [24]. EC has been mainly used to treat various aqueous organic and inorganic wastes [25-27]. It was used also as a method in clarifying potable water $[28,29]$ dechlorophyllation of alcoholic plant extracts and the isolation alkaloids [30].
The effect of $\mathrm{pH}$ on electrocoagulation is also a very pronounced parameter which is taking account. Ghernaout et al. [31], while working on electrocoagulation of bentonite suspensions, they confirmed that $\mathrm{pH}$ has a great effect. Indeed, they found that at acid pH the neutralization of the superficial charges of the clays and at alkaline $\mathrm{pH}$ the enmeshment of the kaolin particles into a sweep floc. At neutral $\mathrm{pH}$, the formed cations $\left(\mathrm{Fe}^{2+}\right.$ and $\mathrm{Fe}^{3+}$ ) neutralize colloidal particles and conduct to the hydroxides $\left(\mathrm{Fe}(\mathrm{OH})_{2}(\mathrm{~s})\right.$ and $\left.\mathrm{Fe}(\mathrm{OH})_{3}(\mathrm{~s})\right)$ which adsorbate colloids and enhance sweep flocculation [31].

Reports concerning the use of electrocoagulation for dechlorophyllation for the Moroccan extracts for the plants studied have not been previously described before in the literature.

In continuation of our investigation of Moroccan aromatic flora, the object of this work is to study and to examine particularly the electrocoagulation as an alternative method of dechlorophyllation since it has received increased attention recently, mainly in the environmental field. To our knowledge, it is for the first time, we report here the dechlorophyllation of alcoholic plant extracts for three Moroccan medicinal plants by electrocoagulation and its influence on the chemical composition.

\section{Materials and methods}

\subsection{Plant material}

The leaves of $P$. crispum were collected in the North of Morocco in April 2016.

The $T$. satureioides were collected from Midelt region (430 km south east of Rabat) in June 2016.

The S. platensis were collected from Laayoune $(650 \mathrm{~km}$ south of Rabat) and purchased from a local market in January 2016.

The plants materials were identified by Professor Leila EL GHAZI from the department of biology, Faculty of Sciences, University Hassan II of Casablanca, Morocco, according to the flora of Morocco [32]. A voucher specimen of the plants of air-dried leaves was deposited in chemistry and biological departments in the same faculty. 


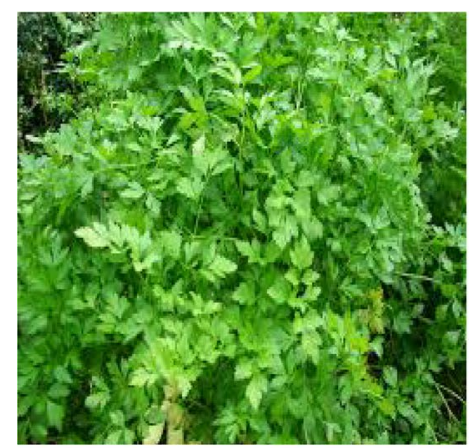

Petroselinum crispum

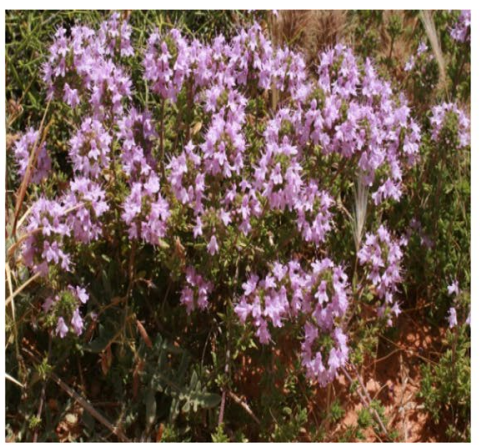

Thymus satureioidis

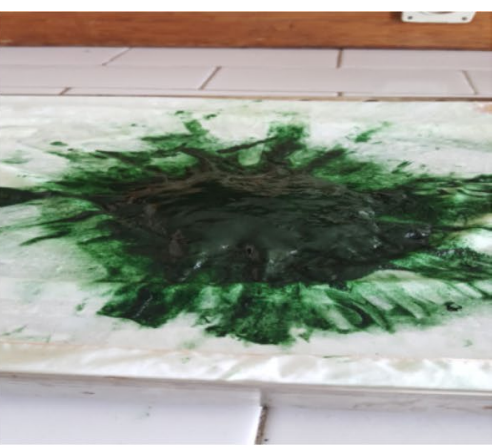

Spirulina platensis

\subsection{Preparation of the alcoholic extract}

$50 \mathrm{~g}$ of each sample plant was extracted with $75 \%$ ethanol $(200 \mathrm{~mL})$ in a Soxhlet apparatus during $8 \mathrm{~h}$. The resulting dark green solution was then subject to electrocoagulation for $2.5 \mathrm{~h}$. The yields were calculated per weight of the dried plant material.

\subsection{Dechlorophyllation by electrocoagulation}

The conditions for electrocoagulation were as follows: two clean aluminium plates were used as electrodes, each of $3 \times 15 \mathrm{~cm}$ dimensions. These were spaced $1.5 \mathrm{~cm}$ apart and dipped $7 \mathrm{~cm}$ into the magnetically-stirred solution containing $0.1 \%(\mathrm{w} / \mathrm{v}) \mathrm{NaCl}$ as supporting electrolyte. The sodium chloride, used as supporting electrolyte, is necessary for the proper conduct of an electrocoagulation reaction, by preventing the formation of deposits on the surface of the anode and accelerating its dissolution and hence the kinetics of reaction.

Direct current (0.9 A, 16.9-31.6 V) from a power supply was then passed via the two electrodes through the solution, which was placed in a jacketed $250 \mathrm{~mL}$ beaker for occasional cooling during electrolysis. After $2.5 \mathrm{~h}$ of electrolysis, the mixture was filtered to afford a decolorized solution $\mathrm{N}^{\circ} 1$. For this solution, the absorbance was measurement by a spectrophotometer (Model UnicoUV-2100) to determine the degree of decolourisation at $665-666 \mathrm{~nm}$ (corresponding to the presence of the green pigments) and at $408-410 \mathrm{~nm}$ (corresponding to the presence of the yellow pigments).

\subsection{Dechlorophyllation by solvent extraction}

Each plant material $(50 \mathrm{~g})$ was extracted with an organic solvent (chloroform) using a Soxhlet apparatus during $8 \mathrm{~h}$. The green solution obtained was drying and $150 \mathrm{~mL}$ of ethanol (75\%) was then added. So as to obtain its dechlorophyllation, the mixture was refluxed for $2 \mathrm{~h}$, and filtered using charcoal and the solution $\mathrm{N}^{\circ} 2$ obtained was taken for absorbance measurement at 665-666 nm and at $408-410 \mathrm{~nm}$.

\subsection{Phytochemical analysis}

The alcoholic crudes extracts of the plants were subjected to qualitative phytochemical screening for the identification of the various classes of active chemical constituents such as saponins, tannins, alkaloids, flavones aglycones, sterols and triterpenes using the method described in the literature [33-37].

\subsubsection{Test for saponins}

Five milliliter of alcoholic extract was vigorously shaken with $10 \mathrm{~mL}$ of distilled water for $2 \mathrm{~min}$. The appearance of foam that persists for at least $15 \mathrm{~min}$ or the forming of an emulsion when olive oil was added confirmed the presence of saponins.

\subsubsection{Test for tannins}

One milliliter of alcoholic extract was mixed with $10 \mathrm{~mL}$ of distilled water and filtered. Ferric chloride $(\mathrm{FeCl})$ reagent (3 drops) was added to the filtrate. A blue-black or green precipitate confirmed the presence of gallic tannins or catechol tannins, respectively.

\subsubsection{Test for alkaloids}

A small portion $(0.2 \mathrm{~mL})$ of the extract was stirred and placed in $1 \%$ aqueous hydrochloric acid $(5 \mathrm{~mL})$ on a steam bath. Then $1 \mathrm{~mL}$ of the filtrate was treated with Mayer's reagent (3 drops) while another portion was similarly treated with Dragedorff's reagent. Turbidity or precipitation with 
these reagents was considered as evidence for the presence of alkaloids.

\subsubsection{Identification of sterols and triterpenes}

The alcoholic extract, $10 \mathrm{~mL}$ was placed in a small beaker and evaporated to dryness. The residue was dissolved in acetic anhydride $(0.5 \mathrm{~mL})$ and chloroform $(0.5 \mathrm{~mL})$. The solution was transferred into a dry test tube and concentrated sulphuric acid $(2 \mathrm{~mL}$ ) was added. Brownish red or violet rings at the zone of the contact with the supernatant and green or violet coloration denoted the presence of sterols and triterpenes.

\subsubsection{Identification of flavone aglycones}

A portion of the extract $(2 \mathrm{~mL})$ was heated, metallic magnesium and concentrated hydrochloric acid; ( 5 drops) were added. A red or orange coloration indicate the presence of flavones aglycones.

\subsection{Total phenolic compounds}

Total phenolic content was determined according to the Folin-Ciocalteu colorimetric method [38]. The sample $(0.5 \mathrm{~mL})$ and $2 \mathrm{~mL}$ of sodium carbonate solution $(75 \mathrm{~g} / \mathrm{L})$ were added to $2.5 \mathrm{~mL}$ of $10 \%$ Folin-Ciocalteu reagent. After 30 min of reaction at room temperature, the absorbance was measured at $765 \mathrm{~nm}$. Gallic acid was used as standard for calibration curve. The results are expressed in mg gallic acid equivalents per gram extract (mg GAE/g extract). All determinations were performed in triplicate.

\subsection{Flavonoids content}

The content of this group of compounds were quantified as described by Ahn et al. [39]. To $0.5 \mathrm{~mL}$ of sample or standard, was added $0.5 \mathrm{~mL}$ of $2 \% \mathrm{AlCl}_{3}$-ethanol solution. After $10 \mathrm{~min}$ at room temperature, the absorbance was measured at $420 \mathrm{~nm}$. Quercetin was used as a standard for plotting the calibration curve, and the results are expressed in mg quercetin equivalents per gram extract (mg of QuE/g extract). Samples were analyzed in triplicate.

\subsection{Polyphenol aglycones preparation}

The polyphenol aglycones preparation was done according to Engida et al. [40]. The alcoholic extract was filtered through a Whatman $\mathrm{N}^{\circ} 2$ filter paper; then the solvent was removed using a rotary evaporator at $60^{\circ} \mathrm{C}$. The dried extract was dissolved in a $88 \%$ aqueous methanol solution $(40 \mathrm{~mL})$, to which $0.5 \mathrm{~g} / \mathrm{L}$ hydroquinone $(\mathrm{HQ})$ and $6 \mathrm{~N} \mathrm{HCl}$ $(10 \mathrm{~mL})$ were added, and the mixture heated at $80^{\circ} \mathrm{C}$ for
$1 \mathrm{~h}$ to hydrolyze glycosides to aglycons. HQ was incorporated as antioxidant to avoid flavonoid degradation. After cooling, the solution was made to a final volume of $100 \mathrm{~mL}$ by adding de-ionized water, and then filtered through a syringe filter for HPLC analysis. Full acid hydrolysis helps us to generate the free polyphenol aglycones contained in the alcoholic extract.

\subsection{Polyphenol aglycones analysis}

\subsubsection{Apparatus and chromatographic conditions}

The HPLC analyses were performed with an Agilent 1100 HPLC Series (Agilent, USA) equipped with a degasser G1322A, a quaternary gradient pump G1311A, an autosampler G1311A, a column oven G1316 A, a Zorbax SB-C18 reversed-phase analytical column $100 \mathrm{~mm} \times 3,0 \mathrm{~mm}$ i.d., $3,5 \mu \mathrm{m}$ particle (Agilent, USA) operated at $48^{\circ} \mathrm{C}$.

The compounds were eluted with an isocratic elution of mobile phase water, acetonitrile, acetic acid $(88 \%, 12 \%$, $1 \%$, respectively). The injection volume of all samples and the mixture of polyphenols standards was $5 \mu \mathrm{l}$. The flow rate was $1 \mathrm{~mL} / \mathrm{min}$. Polyphenols standards ( $10-30 \mathrm{mg} / \mathrm{L}$ ) used were: apigenin, kaempferol, luteolin, quercetol, isoquercitrin, chlorogenic acid, gallic acid, catechin, vanillic acid, caffeic acid, syringic acid, rutin, ferulic acid, p-coumaric acid, sinapic acid and quercetin. Chromatograms were registered at $330 \mathrm{~nm}$. The identification of phenolic compounds in the extract was accomplished by comparison of their retention times with those of pure standards. All the standard were procured from Sigma Chemical Company, USA.

The quantitative analysis of caffeic acid derivates was made using the method described by AFNOR [41] and Lopes-Lutz et al. [42]. A set of seven standard dilutions of caffeic acid at $330 \mathrm{~nm}$ was used. A stock solution of $1 \mathrm{mg} / \mathrm{mL}$ in water, acetonitrile, acetic acid $(88 \%, 12 \%$, $1 \%$, respectively) was prepared and stored at $-20^{\circ} \mathrm{C}$. The

Table 1 Absorbance of plant extracts obtained after dechlorophyllation by electrocoagulation and by solvent extraction

\begin{tabular}{|c|c|c|c|c|}
\hline \multirow[t]{4}{*}{ Plant } & \multicolumn{4}{|l|}{ Absorbance } \\
\hline & \multicolumn{2}{|c|}{ Elecrocoagulation (EC) } & \multicolumn{2}{|c|}{$\begin{array}{l}\text { Solvent extraction } \\
\text { (SE) }\end{array}$} \\
\hline & \multicolumn{2}{|c|}{ Solution $\mathrm{N}^{\circ} 1$} & \multicolumn{2}{|c|}{ Solution $\mathrm{N}^{\circ} 2$} \\
\hline & $\begin{array}{l}\text { Green pig- } \\
\text { ments }\end{array}$ & $\begin{array}{l}\text { Yellow pig- } \\
\text { ments }\end{array}$ & $\begin{array}{l}\text { Green pig- } \\
\text { ments }\end{array}$ & $\begin{array}{l}\text { Yellow } \\
\text { pig- } \\
\text { ments }\end{array}$ \\
\hline P. crispum & 0.18 & 2.40 & 3.18 & 6.23 \\
\hline T. satureioides & 0.34 & 1.15 & 2.70 & 4.70 \\
\hline S. platensis & 0.22 & 1.33 & 1.69 & 3.92 \\
\hline
\end{tabular}




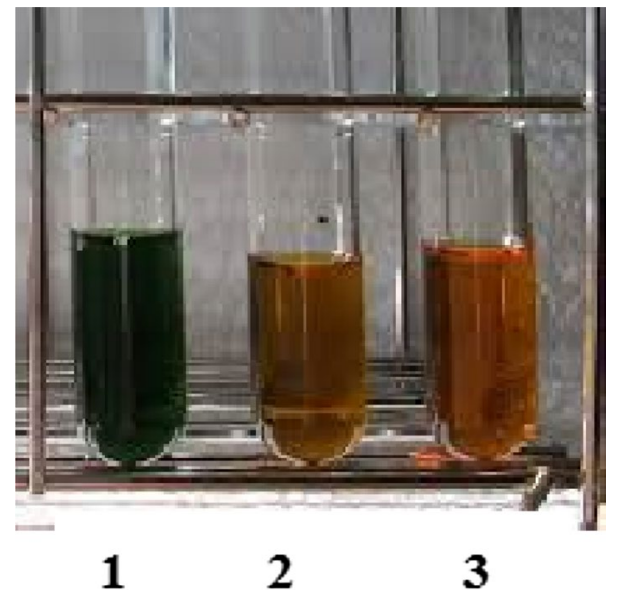

Fig. 1 Extracts color before dechlorophyllation (1), after dechlorophyllation by solvent extraction (2) and electrocoagulation (3)

calibration curves were linear over the range of 1-200 $\mu \mathrm{g} /$ $\mathrm{mL}$ with a correlation coefficient of $\geq 0.99$. For quantification, peak areas were correlated with concentrations in accordance with the calibration curves. Data are reported as means \pm standard deviations of triplicate independent analyses.

The HPLC method was validated in terms of linearity, limits of detection (LOD), limits of quantification (LOQ), recovery and intermediate precision. The calibration curves were linear with correlation coefficient ranging from 0.9909 to 0.9997 . The values of LOD $(0.22-0.93 \mathrm{mg} / \mathrm{L})$, LOQ $(0.65-2.70 \mathrm{mg} / \mathrm{L})$, recovery $(\geq 97.2 \%)$ and precision in terms of retention time (\%RSD $\leq 2.57)$ and peak area (\% $\mathrm{RSD} \leq 5.13$ ) were satisfactory $[43,44]$.

\section{Results and discussion}

The alcoholic extract of $P$. crispum leaf gave a yield of $11.9 \% \mathrm{w} / \mathrm{w}$ and had a dark green colour. The T. satureioides extract gave a yield of $21.2 \% \mathrm{~W} / \mathrm{w}$ and S. platensis extract produced a yield of $8.3 \% \mathrm{w} / \mathrm{w}$.

Table 2 Phytochemical screening of the extracts of $P$. crispum, $T$. satureioides and $S$. platensis
The absorbance at 665-666 $\mathrm{nm}$ corresponding to the green pigments and at $408-410 \mathrm{~nm}$ corresponding to the yellow pigments can be seen in Table 1 and Fig. 1. Examination of these results shows that all the absorbances were particularly high for solvent extraction. They were much lower for electrocoagulation. Indeed, using EC, the absorbance of green pigments was 0.18 for $P$. crispum, 0.34 for T. satureioides and 0.22 for S. platensis; the absorbances of yellow pigments were $2.40,1.15$ and 1.33 respectively for P. crispum, T. satureioides and S. platensis. It seems that dechlorophyllation by EC is more efficient than the conventional solvent fractionation method for all of the plants studied and the variations in absorbance are important between the two techniques. Our results are in accordance with the result previously reported in the literature by Kanlaya et al. [45] while working on the dechlorophyllation of alcoholic extracts from five plants (Solanum laciniatum, Andrographis paniculata, Stevia rebaudiana, Centella asiatica, Cassia siamea) by EC.

The phytochemical screening of $P$. crispum, $T$. satureioides and S. platensis extracts are given in Table 2. As can be seen, the results revealed the presence of saponins, sterols, triterpene, tannins and flavone aglycones. No alkaloids were found. In addition, using SE, the tannins were found in all extracts, but they were absent using EC. In our case, electrocoagulation seems be an interesting method to remove the chlorophylls pigments and tannins which usually affect the quality of the extracts, than the conventional solvent fractionation method. The tannins, owing to their polyphenolic nature, are easily coagulated by the phenolate salt forming mechanism in addition to the adsorption mechanism [46]. In the context of electrocoagulation with electrodes of $\mathrm{Al}$, in our case, if we consider tannins and chlorophylls pigments negatively charged colloids, they will tend to migrate towards the anode where there is oxidation of the aluminum (Reactions 1 and 2). They then increase the possibility of meeting with oxidized aluminum. This explains their elimination in the process of electrocoagulation [26].

$\mathrm{Al} \rightarrow \mathrm{Al}^{3+}+3 \mathrm{e}^{-}$

(Reaction 1)

\begin{tabular}{|c|c|c|c|c|c|c|}
\hline \multirow[t]{2}{*}{ Chemical constituents } & \multicolumn{2}{|c|}{ P. crispum } & \multicolumn{2}{|c|}{ T. satureioides } & \multicolumn{2}{|c|}{ S. platensis } \\
\hline & SE & EC & SE & $\mathrm{EC}$ & SE & EC \\
\hline Saponins & - & - & ++ & + & + & ++ \\
\hline Tannins & +++ & - & ++ & - & ++ & - \\
\hline Alkaloid & - & - & - & - & - & - \\
\hline Sterols and triterpene & + & + & ++ & + & ++ & + \\
\hline Flavone aglycones & ++ & ++ & ++ & +++ & + & ++ \\
\hline
\end{tabular}

$E C$ elecrocoagulation and SE solvent extraction

- Negative result, + Positive result, ++ Present in high concentration and +++ Present in very high concentration 
Table 3 Concentration of total phenols and flavonoid in extracts of $P$. crispum, $T$. satureioides and S. platensis

\begin{tabular}{|c|c|c|c|c|c|c|}
\hline & \multicolumn{2}{|l|}{ P. crispum } & \multicolumn{2}{|c|}{ T. satureioides } & \multicolumn{2}{|l|}{ S. platensis } \\
\hline & SE & $\mathrm{EC}$ & SE & $\mathrm{EC}$ & SE & $\mathrm{EC}$ \\
\hline $\begin{array}{l}\text { Total phenolics } \\
\text { mg of GAE/g } \\
\text { extract }\end{array}$ & $36.5 \pm 0.4$ & $39.5 \pm 0.4$ & $69.5 \pm 0.4$ & $70.2 \pm 0.4$ & $29.5 \pm 0.4$ & $28.4 \pm 0.4$ \\
\hline $\begin{array}{l}\text { Total flavonoid } \\
\text { mg of QE/g } \\
\text { extract }\end{array}$ & $27.2 \pm 0.01$ & $33.2 \pm 0.01$ & $49.2 \pm 0.01$ & $52.7 \pm 0.01$ & $22.2 \pm 0.01$ & $19.6 \pm 0.01$ \\
\hline
\end{tabular}

Results are given as mean \pm standard deviation of three different experiments

$G A E$ gallic acid equivalents, $Q E$ quercetin equivalents, $E C$ elecrocoagulation and $S E$ solvent extraction
Fig. 2 HPLC Chromatogram of available polyphenol standards monitored at $330 \mathrm{~nm}$ and identified with retention time ( $\mathrm{min}$ ) gallic acid (2.80), vanillic acid (4.47), caffeic acid (9.45), syringic acid (11.15), catechin (19.7), ferulic acid (22.31), p-coumaric acid (26.51), sinapic acid (29.02), chlorogenic acid (35.12), isoquercitrin (40.14), rutin (46.25), quercetol (48.65), luteolin (53.17), kaempferol (55.39), quercetin (60.12) and apigenin (65.09)

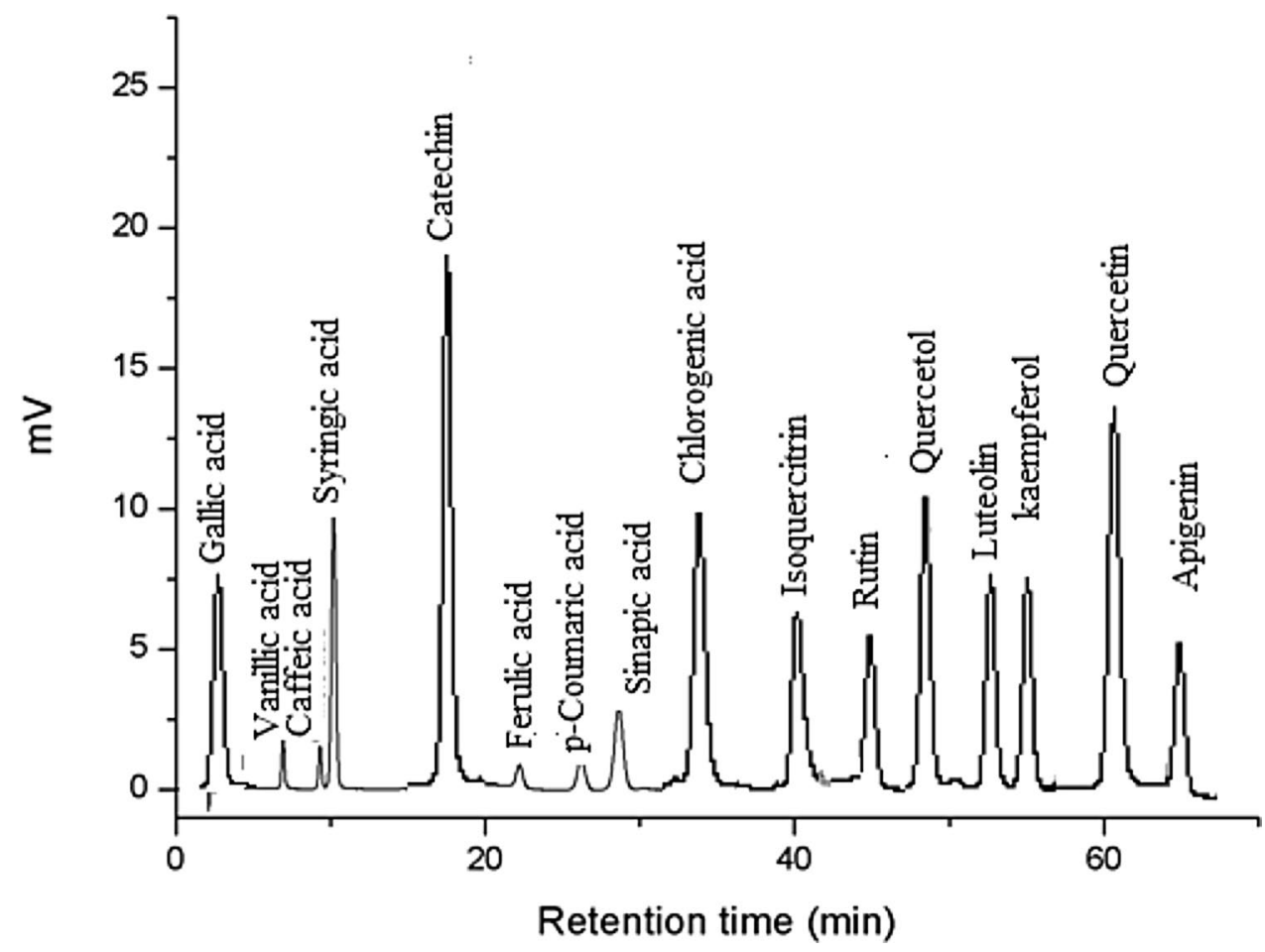

(Reaction 2)

To ensure that the chemical composition is not affected by the process of electrocoagulation, we also focused our study on the qualitative and quantitative analysis of polyphenol aglycones in the extracts. HPLC chromatogram of available polyphenol standards monitored at $330 \mathrm{~nm}$ is given in Fig. 2. The identified components and their percentages are given in Table 4.

The results shown that both EC and SE techniques, after acidic hydrolysis of the hydroalcoholic extract, the HPLC analysis revealed the presence of the same compounds in each plant and the qualitative and quantitative chemical composition is not affected by EC. For $P$. crispum five components were identified such as vanillic acid, luteolin, kaempferol, quercetin and apigenin. Some compounds have been previously reported from parsley 
Table 4 Phenolic compounds (\% of total) identified by HPLC, in the alcoholic extract of Moroccan medicinal plants after acidic hydrolysis

\begin{tabular}{|c|c|c|c|c|c|c|c|c|}
\hline \multirow[t]{3}{*}{ Peak $N^{\circ}$} & \multirow[t]{3}{*}{ Compounds } & \multirow{3}{*}{$\begin{array}{l}\text { Retention } \\
\text { time (min) }\end{array}$} & \multicolumn{6}{|c|}{ Concentration (mg/100 g) } \\
\hline & & & \multicolumn{2}{|c|}{ P. crispum } & \multicolumn{2}{|c|}{ T. satureioides } & \multicolumn{2}{|c|}{ S. platensis } \\
\hline & & & SE & $\mathrm{EC}$ & SE & $\mathrm{EC}$ & SE & $\mathrm{EC}$ \\
\hline 1 & Gallic acid & 2.80 & - & - & - & - & 66.2 & 59.8 \\
\hline 2 & Vanillic acid & 4.47 & 2.1 & 1.5 & - & - & - & - \\
\hline 3 & Caffeic acid & 9.45 & - & - & 114.3 & 120.8 & 44.1 & 41.3 \\
\hline 4 & Syringic acid & 11.15 & - & - & - & - & - & - \\
\hline 5 & Catechin & 19.7 & - & - & - & - & - & - \\
\hline 6 & Ferulic acid & 22.31 & - & - & 77.9 & 80.1 & - & - \\
\hline 7 & p-coumaric acid & 26.51 & - & - & 63.4 & 59.8 & 11.5 & 9.8 \\
\hline 8 & Sinapic acid & 29.02 & - & - & - & - & - & - \\
\hline 9 & Chlorogenic acid & 35.12 & - & - & 42.1 & 39.7 & - & - \\
\hline 10 & Isoquercitrin & 40.14 & - & - & - & - & - & - \\
\hline 11 & Rutin & 46.25 & - & - & - & - & 12.3 & 14.1 \\
\hline 12 & Quercetol & 48.65 & - & - & - & - & - & - \\
\hline 13 & Luteolin & 53.17 & 47.2 & 48.6 & 35.1 & 33.8 & - & - \\
\hline 14 & Kaempferol & 55.39 & 12.7 & 11.3 & - & - & - & - \\
\hline 15 & Quercetin & 60.12 & 9.1 & 8.9 & - & - & 5.4 & 6.1 \\
\hline 16 & Apigenin & 65.09 & 4.8 & 5.5 & 1.7 & 2.3 & - & - \\
\hline
\end{tabular}

EC elecrocoagulation and SE solvent extraction

- Not identified extracts such as quercetin, luteolin, kaemferol [3] and apigenin [4].

For T. satureioides, six compounds were identified such as caffeic acid, ferulic acid, p-coumaric acid, chlorogenic acid, luteolin and apigenin. Those compounds have been previously reported in $T$. satureioides leaves by Ismaili et al. [48].

For S. platensis five components were identified such as gallic acid, caffeic acid, p-coumaric acid, rutin and quercetin. Machu et al. [47] reported the presence in the extract of S. platensis from India different phenolic compounds such as catechin hydrate, epicatechin, and pyrocatechol not present in our sample.

\section{Conclusion}

The electrocoagulation technique was found be an interesting method for dechlorophyllation of our plant extracts than the conventional usage of organic solvents. It seems also not affecting the chemical composition. In Morocco, the result of this investigation will allow us to examine the possibility to promote this technique as other alternative environmentally friendly method to remove from the plants extracts the pigments, notably the chlorophylls.
Acknowledgements The authors are grateful to Dr. Abdelilah Aboulayt, Laboratory of Physical Chemistry of Inorganic Materials (LPCMI), Faculty of Science Ain Chock, for his invaluable help in researching and entering bibliographic references.

Funding Kouar Jihane has received research grants from the Ministry of Higher Education and Scientific Research of Morocco.

\section{Compliance with ethical standards}

Conflict of interest On behalf all coauthors, I confirm that we not have conflict of interest with any reviewers or any financial and personal relationships with other people or organizations that could inappropriately influence our work.

\section{References}

1. Agyare C, Appiah T, Boakye YD, Apenteng JA (2017) Chapter 25, Petroselinum crispum: a Review. In: Medicinal spices and vegetables from Africa. pp. 527-547. https://doi.org/10.1016/B9780-12-809286-6.00025-X

2. Bellakhdar J (2003) Le Maghreb à travers ses plantes: plantes, productions végétaleset traditions au Maghreb. Editions Le Fennec. $198 \mathrm{pp}$

3. Zhang H, Chen F, Wang X, Yao HY (2006) Evaluation of antioxidant activity of parsley (Petroselinum crispum) essential oil and identification of its antioxidant constituents. Food Res Int 39:833-839. https://doi.org/10.1016/j.foodres.2006.03.007

4. Pápay ZE, Kósa A, Boldizsár I, Ruszkai A, Balogh E, Klebovich I, Antal I (2012) Pharmaceutical and formulation aspects of 
Petroselinum crispum extract. Acta Pharm Hung 82: 3-14. http:// www.ncbi.nlm.nih.gov/pubmed/22570982

5. Chaudhary SK, Ceska O, Têtu C, Warrington PJ, Ashwood-Smith MJ, Poulton GA (1986) Oxypeucedanin, a major furocoumarin in parsley, Petroselinum crispum. Planta Med 462:462-464. https ://doi.org/10.1055/s-2007-969254

6. Bellakhadar J, Claiss R, Fleurentin J, Younos C (1991) Repertory of standard herbal drugs in the Moroccan pharmacopoea. J Ethnopharmacol 35:123-143

7. Tantaoui-Elaraki A, Lattaoui N, Errifi A, Benjilali B (1993) Composition and antimicrobial activity of the essential oils of Thymus broussonettii, T. zygis and T. satureioides. J Essent Oil Res 5:45-53. https://doi.org/10.1080/10412905.1993.9698169

8. Vonshak A (1997) Spirulina platensis (Arthrospira): physiology, cell-biology and biotechnology. Taylor, London, pp 1-16

9. Dillon JC, Phuc AP, Dubacq JP (1995) Nutritional value of the alga Spirulina. World Rev Nutr Diet 77:32-46. https://doi. org/10.1159/000424464

10. Wu Q, Liu L, Miron A, Klímová B, Wan D, Kuča K (2016) The antioxidant, immunomodulatory, and anti-inflammatory activities of Spirulina: an overview. Arch Toxicol 90:1817-1840. https://doi. org/10.1007/s00204-016-1744-5

11. Ould Bellahcen T, Bouchabchoub A, Massoui M, El Yachioui M (2013) Culture Et production De Spirulina Platensis Dans Les Eaux Usees Domestiques. Larhyss J 14:107-122

12. Ambrozova JV, Misurcova L, Vicha R, Machu L, Samek D, Baron M, Mlcek J, Sochor J, Jurikova T (2014) Influence of extractive solvents on lipid and fatty acids content of edible freshwater algal and seaweed products, the green microalga Chlorella kessleri and the cyanobacterium Spirulina platensis. Molecules 19:2344-2360. https://doi.org/10.3390/molecules19022344

13. Bellakhdar J (1997) La pharmacopée marocaine traditionnelle, Médecine arabe ancienne et savoirs populaires. Ibis Press. http://www.bibliomonde.com/livre/pharmacopee-marocainetraditionnelle-132.html. Accessed 08 Dec 2018

14. Subhashini J, Mahipal SVK, Reddy MC, Reddy MM, Rachamallu A, Reddanna P (2004) Molecular mechanisms in C-Phycocyanin induced apoptosis in human chronic myeloid leukemia cell line-K562. Biochem Pharmacol 68:453-462. https://doi. org/10.1016/j.bcp.2004.02.025

15. Hirahashi T, Matsumoto M, Hazeki K, Saeki Y, Ui M, Seya T (2002) Activation of the human innate immune system by Spirulina: augmentation of interferon production and NK cytotoxicity by oral administration of hot water extract of Spirulina platensis. Int Immunopharmacol 2:423-434. https://doi.org/10.1016/S1567 -5769(01)00166-7

16. Ozdemir G, Ulku Karabay N, Dalay MC, Pazarbasi B (2004) Antibacterial activity of volatile component and various extracts of Spirulina platensis. Phyther Res 18:754-757. https://doi. org/10.1002/ptr.1541

17. Mallikarjun Gouda KG, Udaya Sankar K, Sarada R, Ravishankar GA (2014) Criblage phytochimique Et evaluation. J Food Sci Technol. https://doi.org/10.1007/s13197-014-1426-3

18. Madhyastha HK, Sivashankari S, Vatsala TM (2009) C-phycocyanin from Spirulina fussiformis exposed to blue light demonstrates higher efficacy of in vitro antioxidant activity. Biochem Eng J 43:221-224. https://doi.org/10.1016/j.bej.2008.11.001

19. Suetsuna K, Chen JR (2001) Identification of antihypertensive peptides from peptic digest of two microalgae, Chlorella vulgaris and Spirulina platensis. Mar Biotechnol 3:305-309. https://doi. org/10.1007/s10126-001-0012-7

20. Lu J, Ren DF, Xue YL, Sawano Y, Miyakawa T, Tanokura M (2010) Isolation of an antihypertensive peptide from alcalase digest of spirulina platensis. J Agric Food Chem 58:7166-7171. https://doi. org/10.1021/jf100193f
21. Elamrani A (2011) The antitumoral activity and the cytotoxicity on renal cells of ethanolic extracts from the leaves of four varieties of Olea europaea L. Grown in Morocco. Anal Chem Lett 1:63-69. https://doi.org/10.1080/22297928.2011.10648205

22. Elamrani A, Benaissa M (2010) Chemical composition and antibacterial activity of the essential oil of Ononis natrix from Morocco. J Essent Oil-Bear Plants 13:477-488. https://doi. org/10.1080/0972060X.2010.10643852

23. Pigni NB, Berkov $S$, Elamrani $A$, Benaissa $M$, Viladomat $F$, Codina C, Bastida J (2010) Two new alkaloids from Narcissus serotinus L. Molecules 15:7083-7089. https://doi.org/10.3390/molecules1 5107083

24. De Pauli AR, Espinoza-Quiñones FR, Dall'Oglio IC, Trigueros DEG, Módenes AN, Ribeiro C, Borba FH, Kroumov AD (2017) New insights on abatement of organic matter and reduction of toxicity from landfill leachate treated by the electrocoagulation process. J Environ Chem Eng 5:5448-5459. https://doi. org/10.1016/j.jece.2017.10.017

25. Lakshmi Kruthika N, Karthika S, Bhaskar Raju G, Prabhakar S (2013) Efficacy of electrocoagulation and electrooxidation for the purification of wastewater generated from gelatin production plant. J Environ Chem Eng 1:183-188. https://doi. org/10.1016/j.jece.2013.04.017

26. Matteson MJ, Dobson RL, Glenn RW, Kukunoor NS, Waits WH, Clayfield EJ (1995) Electrocoagulation and separation of aqueous suspensions of ultrafine particles. Colloids Surf A Physicochem Eng Asp 104:101-109. https://doi.org/10.1016/09277757(95)03259-G

27. Buso A, Balbo L, Giomo M, Farnia G, Sandonà G (2000) Electrochemical removal of tannins from aqueous solutions. Ind Eng Chem Res 39:494-499. https://doi.org/10.1021/ie990192a

28. Vik EA, Carlson DA, Eikum AS, Gjessing ET (1984) Electrocoagulation of potable water. Water Res 18:1355-1360. https://doi. org/10.1016/0043-1354(84)90003-4

29. Mameri N, Yeddou AR, Lounici H, Belhocine D, Grib H, Bariou B (1998) Defluoridation of septentrional Sahara water of North Africa by electrocoagulation process using bipolar aluminum electrodes. Water Res 32:1604-1612. https://doi.org/10.1016/ S0043-1354(97)00357-6

30. Phutthawong N, Jumpatong K, Chairungsi N, Wangkarn S (2007) Application of electrocoagulation to the isolation of alkaloids. Chiang Mai J Sci 34:127-133

31. Ghernaout D, Ghernaout B, Boucherit A (2008) Effect of pH on electrocoagulation of bentonite suspensions in batch using iron electrodes. J Dispers Sci Technol 29:1272-1275

32. Jahandiez V, Maire R, Emberger L (1941) Catalogue des plantes du Maroc (spermatophytes et ptéridophytes). Imprimerie Minerva, Alger

33. Karumi YOVO, Onyeyili PA (2004) Identification of active principles of M. balasamina (Balsam Apple) leaf extract. J Med Sci 4:179-182

34. Benmehdi $\mathrm{H}$, Hasnaoui O, Benali O, Salhi F (20132) Phytochemical investigation of leaves and fruits extracts of Chamaerops humilis L. J Mater Environ Sci 3:320-327. ISSN 2028-2508

35. Shah B, Seth A (2010) Textbook of pharmacognosy and phytochemistry, INDIA, ELS

36. Evans WC (2002) Trease and evans pharmacognosy. WB Saunders, Edinburgh

37. Ilboudo S, Ouedraogo M, Some N, Ouedraogo M, Ouedraogo M, Guissou PI (2009) Criblage Phytochimique Et Evaluation De La Toxicite Aigue De Pisolithus Tinctorius (Basidiomycète). J Sci Pharm Biol 10:6-13. http://www.ufrspb.ci/cf/doc2_87.pdf

38. Singleton VL, Rossi JA Jr (1965) Colorimetry of total phenolics with phosphomolybdic-phosphotungstic acid reagents. Am J Enol Vitic 16:144-158. https://doi.org/10.12691/ijebb-2-1-5 
39. Ahn M, Kumazawa S, Usui Y, Nakamura J (2007) Antioxidant activity and constituents of propolis collected in various areas of China. Food Chem 101:1383-1392. https://doi.org/10.1016/j. foodchem.2006.03.045

40. Engida AM, Kasim NS, Tsigie YA, Ismadji S, Huynh LH, Ju YH (2013) Extraction, identification and quantitative HPLC analysis of flavonoids from sarang semut (Myrmecodia pendan). Ind Crops Prod 41:392-396. https://doi.org/10.1016/j.indcr op.2012.04.043

41. AFNOR - NF EN 14148:Foodstuffs-determination of vitamin k1 by HPLC (2004)

42. Lopes-Lutz D, Dettmann J, Nimalaratne C, Schieber A (2010) Characterization and quantification of polyphenols in amazon grape (Pourouma cecropiifolia martius). Molecules 15:85438552. https://doi.org/10.3390/molecules15118543

43. Kazusaki M, Ueda S, Takeuchi N, Ohgami Y (2012) Validation of analytical procedures by high-performance liquid chromatography for pharmaceutical analysis. Chromatography 33:65-73
44. Huber L (1999) Validation of HPLC methods. BioPharm 12:1-8

45. Jumpatong K, Phutdhawong W, Buddhasukh D (2006) Dechlorophyllation by electrocoagulation. Molecules 11:156-162. https ://doi.org/10.3390/11020156

46. Hutdhawong WP, Howwanapoonpohn SC, Uddhasukh DB (2000) Electrocoagulation and subsequent recovery of phenolic compounds. Anal Chem 16:1083-1084. https://doi.org/10.2116/ analsci.16.1083

47. Machu L, Misurcova L, Ambrozova JV, Orsavova J, Mlcek J, Sochor J, Jurikova T (2015) Phenolic content and antioxidant capacity in algal food products. Molecules 20:1118-1133. https ://doi.org/10.3390/molecules20011118

48. Ismaili H, Milella L, Fkih-Tetouani S, Ilidrissi A, Camporese A, Sosa S, Altinier G, Della Loggia R, Aquino R (2004) In vivo topical antiinflammatory and in vitro antioxidant activities of two extracts of Thymus satureioides leaves. J Ethnopharmacol 91:31-36. https ://doi.org/10.1016/j.jep.2003.11.013 